\title{
SLEDOVI PLEISTOCENSKE POLEDENITVE NA TRNOVSKEM GOZDU
}

\author{
Manja Žebre*, dr. Uroš Stepišnik**, Blaž Kodelja**** \\ *Groharjeva 8, SI-I24I Kamnik \\ **Oddelek za geografijo, Filozofska fakulteta Univerze v Ljubljani, Aškerčeva 2, SI-I000 \\ Ljubljana \\ ***Študent geografije na Oddelku za geografijo Filozofske fakultete Univerze v Ljubljani \\ e-mail:manjazebre@gmail.com, uros.stepisnik@gmail.com, blaz.kodelja@gmail.com \\ Izvirni znanstveni članek
}

COBISS 1.01

DOI: $10.43121 /$ dela.39.9.157-170

\section{Izvleček}

Trnovski gozd je visoka kraška planota na dinarskem krasu zahodne Slovenije, ki so jo v pleistocenu preoblikovali tudi ledeniški procesi. Ugotovili smo, da je severna pobočja in podnožje najvišjega osrednjega grebena Golaki pokrival ledenik s površino $4,8 \mathrm{~km}^{2}$ in največjo debelino okoli $180 \mathrm{~m}$. V več odtočnih ledenikih je padal preko strme reliefne stopnje v dolini Belce in Trebuše ter na Hudo polje. Prisojna pobočja Golakov niso bila poledenela. Z metodama deleža akumulacijskega dela ledenika ter zgornje meje bočnih moren smo izračunali ravnovesno mejo ledenikov na višini $1240 \mathrm{~m}$.

Ključne besede: pleistocen, poledenitev, ravnovesna meja ledenikov, paleoklima, Trnovski gozd, Slovenija

\section{TRACES OF PLEISTOCENE GLACIATION ON TRNOVSKI GOZD}

\begin{abstract}
Trnovski gozd is a high karst plateau situated in the Dinaric Mountains of western Slovenia which was modified by glacial action in the Pleistocene. With our research we concluded that slopes with northern exposure and the footslope of the highest ridge of Golaki had an glacier up to $180 \mathrm{~m}$ thick with an area of $4.8 \mathrm{~km}^{2}$. Several outlet glaciers were found to have been drifting over a steep escarpment from the plateau to the valleys of Belca, Trebuša and on the Hudo polje plateau. There was no evidence of glaciation on southern exposed slopes. The equilibrium line altitude was established via the accumulation-area ratio method on an elevation of $1240 \mathrm{~m}$.
\end{abstract}

Key words: Pleistocene, glaciation, equilibrium line altitude, paleoclimate, Trnovski gozd, Slovenia 


\section{UVOD}

Trnovski gozd je visoka kraška planota $\mathrm{v}$ najsevernejšem delu dinarskega krasa $\mathrm{v}$ zahodni Sloveniji. Zgrajen je pretežno iz apnencev in dolomitov, kar se kaže v popolni prevladi kraškega geomorfnega sistema. Najvišje nadmorske višine doseže v 1495 m visokem Malem Golaku. Na severu meji na globoki dolini Trebuše in Belce, na severozahodu ga od Banjšic loči Čepovanski dol. Znižano površje med Črnim Vrhom in Colom ga na jugovzhodu ločuje od Nanosa in Hrušice, na jugu in jugozahodu pa se pobočja planote strmo spuščajo v Vipavsko dolino. Kraško območje Trnovskega gozda je bilo v pleistocenu izrazito preoblikovano z ledeniškim delovanjem.

Sledove pleistocenske poledenitve na Trnovskem gozdu so preučevali Melik (1959), Buser (1965) in Habič (1968). Dosedanji rezultati in interpretacije o poledenitvi Trnovskega gozda se ne skladajo z našimi rezultati raziskav na Trnovskem gozdu. Osnovni namen naše raziskave je bila reinterpretacija dosedanjih ugotovitev obsega pleistocenske poledenitve Trnovskega gozda in rekonstrukcija ravnovesne meje ledenikov. Za cilj smo si zadali podrobno morfografsko analizo ledeniških sedimentov ter morfometrično analizo bočnih in čelnih morenskih kompleksov, na podlagi katerih smo rekonstruirali obseg poledenitve celotnega območja. Cilj raziskave je obsegal tudi rekonstrukcijo topografije ledeniškega površja, na osnovi katere smo izračunali višino pleistocenske ravnovesne meje.

\section{REGIONALNE ZNAČILNOSTI}

Celotno območje Trnovskega gozda je globoki raztočni kras. Globina neprežete cone na območju je več kot $500 \mathrm{~m}$, v podzemlju pa se raztekajo avtigene vode proti številnim izvirom v podnožju planote. $\mathrm{V}$ podzemlju tako prevladujejo predvsem brezna vadozne cone (Mihevc, 1995; Mihevc, 1997), površje pa je tipično kraško z vsemi značilnimi oblikami. Zaradi pestre litološke sestave prihaja do razlik v lokalni oblikovanosti površja, ki so rezultat različnega načina preperevanja kamnine in transporta prepereline.

V morfološkem smislu Trnovski gozd ni enotna kraška planota, ampak je sestavljen iz grebenov in vmesnih podolij ter robnih uravnav. Najvišji in najmasivnejši je greben Golakov z višinami najvišjih vrhov od 1400 do $1495 \mathrm{~m}$. V osrednjem delu se dviga nekoliko višji hrib Mrzovec (1407 m), na južnem robu pa Čaven (1186 m). V višjih delih Trnovskega gozda in na severnih pobočjih Golakov je več velikih kotanj, kont in drag. Največje so Mrzla, Mojska, Smrekova in Črna draga (Habič, 1968; Janež in sod., 1997). Ob vznožju Golakov so širše uravnave; najobsežnejša je Voglarska planota v zahodnem delu Trnovskega gozda, v južnem delu pa je Otliška planota (Habič, 1968; Janež in sod., 1997).

Območje Trnovskega gozda geotektonsko pripada trnovskemu pokrovu, ki je narinjen na hrušiški pokrov oziroma na eno izmed vmesnih lusk. Paleogeografsko gradijo Trnovski gozd plitvomorske karbonatne kamnine Dinarske karbonatne platforme mezozojske starosti, ki so narinjene na eocenske flišne kamnine. V severnem delu Trnovskega gozda, kjer smo v okviru naše raziskave identificirali sledove poledenitve, je najstarejši litostratigrafski horizont zgornjetriasni norijsko-retijski glavni dolomit, ki navzgor prehaja 
$\mathrm{v}$ plastnat dolomit in dachsteinski apnenec. Triasne plasti zvezno prehajajo v jurske, ki na Trnovskem gozdu prevladujejo, gradijo pa jih različni apnenci in dolomiti. Kredne plasti, ki jih gradijo predvsem različni apnenci, so le v zahodnem delu Trnovskega gozda. Najmlajše kamnine so eocenski fliši, v katerih so spodnji deli južnih pobočij Trnovskega gozda. Na severnih in južnih pobočjih Trnovskega gozda so prisotni tudi grušči in breče kvartarne starosti. Enake starosti so tudi ilovice, ki zapolnjuje dna kotanj v osrednjem delu Trnovskega gozda in so nastale s preperevanjem zgornjejurskih apnencev z roženci (Buser, 1965; Osnovna geološka karta SFRJ, list Gorica, 1968; Osnovna geološka karta SFRJ, list Tolmin in Udine (Videm), 1986; Janež in sod., 1997).

Trnovski gozd predstavlja izrazito reliefno pregrado med toplejšimi morskimi vplivi na južni in hladnejšimi celinskimi vremenskimi vplivi na severni strani, podnebje na najvišjem osrednjem delu Trnovskega gozda pa je gorsko (Ogrin, D., 1996; Ogrin, D., Plut, 2009). Predgorje Trnovskega gozda prejme 1400-1600 mm padavin, na strukturni stopnji nad Vipavsko dolino je 1700-2000 mm, na območju Golakov pa celo do $3200 \mathrm{~mm}$ padavin (Klimatografija Slovenije, 1989). Ostro gorsko podnebje in trda karbonatna matična podlaga pogojujeta skoraj popolno prevlado rendzin ter bukovih gozdnih združb, še posebej bukve in spomladanske torilnice (Omphalodo-Fagetum; Repe, 2010).

\section{PREGLED DOSEDANJEGA PREUČEVANJA}

Zaradi pestre geološke in geomorfološke zgradbe so o Trnovskem gozdu pisali številni raziskovalci od sredine 19. st. dalje (Janež in sod., 1997). Obstoj pleistocenske poledenitve na Trnovskem gozdu je prvi ugotovil Melik (1959). Identificiral je nekaj talnih in čelnih moren na grebenu Golakov in na njegovih severnih pobočjih. Sklepal je, da je bilo severno pobočje Golakov poledenelo, led pa naj bi zapolnjeval Smrekovo drago in celo padal preko njenega severnega oboda v dolino Trebuše. Poledenitev naj bi zavzemala okoli $10 \mathrm{~km}^{2}$. Ugotovil je, da je bila pleistocenska snežna meja na nadmorski višini $1300 \mathrm{~m}$. Metode določevanja snežne meje ni pojasnil. Nekaj let kasneje je o poledenitvi pisal Buser (1965) in se večinoma strinjal z Melikovo razlago obsega poledenitve.

Najtemeljitejše delo o geomorfoloških značilnostih Trnovskega gozda, ki vključuje tudi interpretacijo poledenitve, je napisal Habič (1968). Ugotovil je, da so bila poledenela vsa območja nad višino 1300 m, kar znaša okoli $40 \mathrm{~km}^{2}$ površine. Ledeniki naj bi prekrivali celoten greben Golakov ter najvišje dele Čavna in Mrzovca, od koder naj bi se stekali v nižje predele. Poledenela naj bi bila prisojna pobočja Golakov vse do nadmorske višine 1000 m, na osojni strani pa naj bi led prekrival Mojsko, Smrekovo in Črno drago ter planotasto površje pod Golaki. Od tod naj bi ledenik padal preko strme reliefne stopnje $\mathrm{v}$ dolini Trebuše in Belce ter na Hudo polje (slika 1).

Obseg poledenitve je Habič (1968) interpretiral na osnovi ledeniških oblik, predvsem različnih tipov moren. Posredno je obseg določil tudi na osnovi oblik, ki so vezane na odtok ledeniških vod, kot so erozijski jarki in konte. Natančne metode določitve snežne meje, ki bi temeljila na ledeniških akumulacijah in drugih geomorfnih oblikah, Habič (1968) ni pojasnil. Na osojnih legah je pleistocensko snežno mejo določil na nadmorski višini $1035 \mathrm{~m}$, na prisojnih legah pa na okoli $1200 \mathrm{~m}$. 
Slika 1: Obseg pleistocenske poledenitve na Trnovskem gozdu po Meliku (1959) in Habiču (1968)

Figure 1: The extent of Pleistocene glaciation on Trnovski gozd according to Melik (1959) and Habič (1968)

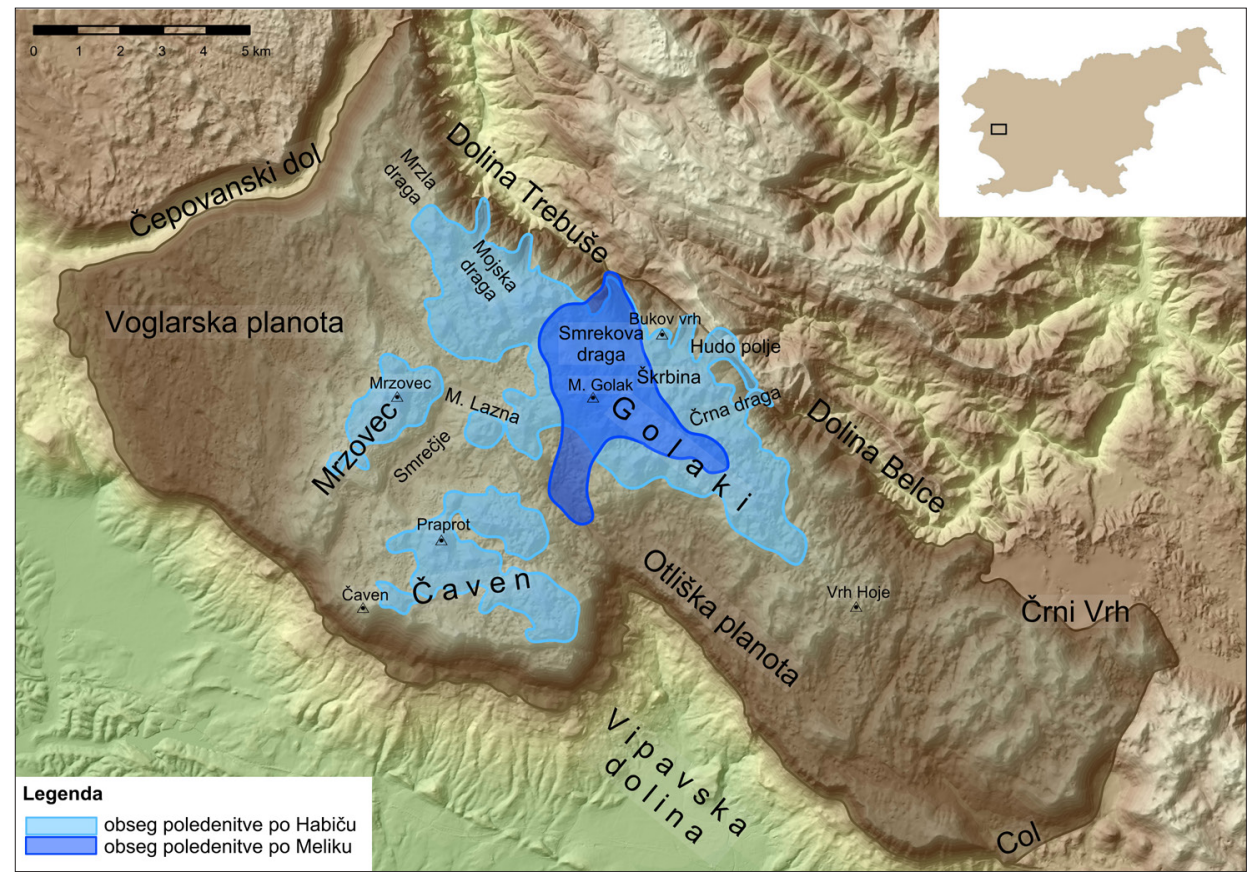

\section{METODOLOGIJA}

\section{I. Morfografska in morfometrična analiza}

Morfografska analiza je temeljila na detajlnem pregledu območja, identifikaciji ledeniških oblik in njihovi prostorski dokumentaciji na kartah v merilu $1: 10.000$. Podrobno smo pregledali severna pobočja Golakov, Čavna in Mrzovca ter celotno območje, za katerega je predhodna literatura navajala poledenitev. Pregledali smo tudi dna in pobočja kont, saj naj bi bile zaradi temperaturne inverzije zapolnjene $\mathrm{z}$ ledom. Morfometrična analiza je temeljila na analizi kartografskega gradiva in digitalnega modela nadmorskih višin, del morfometričnih podatkov smo pridobili na terenu s pomočjo barometričnega višinomera.

\subsection{Rekonstrukcija topografije ledenikov}

Podatke morfografske in morfometrične analize smo uporabili pri numeričnem modeliranju podolžnega profila ledeniškega površja (Benn, Hulton, 2010), s katerim smo 
rekonstruirali topografijo ledenikov na Trnovskem gozdu. Model podolžnega profila ledeniškega površja je primeren za površinsko majhne ledenike, pri katerih je topografija podlage izjemno razgibana. Površje ledenika na asimetrični podlagi izračunamo z zaporedjem posamičnih korakov (Benn, Hulton, 2010):

$$
h_{i+1}^{2}-h_{i+1}\left(B_{i}+B_{i+1}\right)+h_{i}\left(B_{i+1}-H_{i}\right)-\frac{2 \Delta x \overline{\tau_{y}}}{\rho g}=0
$$

$\rho=$ gostota ledeniškega ledu $\left(\sim 900 \mathrm{kgm}^{-3}\right), \mathrm{g}=$ težnostni pospešek $\left(9,81 \mathrm{~ms}^{-2}\right), \mathrm{H}=$ debelina ledu, $\mathrm{B}=$ nadmorska višina podlage ledenika, $\mathrm{h}=$ nadmorska višina ledeniškega površja in $\overline{\tau_{y}}=$ meja plastičnosti.

Pri modeliranju smo uporabili vrednosti meje plastičnosti med 50 in $150 \mathrm{kPa}$, saj se v tem intervalu gibljejo izračunane vrednosti za ledeniški led (Paterson, 1994). Pravilo za določitev optimalne vrednosti meje plastičnosti za posamezno območje ledenika ne obstaja (Benn, Hulton, 2010), zato smo vrednosti meje plastičnosti na posamezni točki vzdolžnega profila ledeniškega površja prilagodili ciljnim vrednostim (Benn, Hulton, 2010). Ciljne vrednosti so bili na terenu evidentirani morfografski in morfometrični podatki o debelini ledenikov.

\subsection{Rekonstrukcija ravnovesne meje ledenikov}

Pleistocensko ravnovesno mejo ledenikov na Trnovskem gozdu smo izračunali po metodah deleža akumulacijskega dela ledenika (angl. accumulation-area ratio method; Meier, Post, 1962; Porter, 1975; Torsnes, Rye, Nesje, 1993) in zgornje meje bočnih moren (angl. maximum elevation of lateral moraines).

Metoda deleža akumulacijskega dela ledenika temelji na predpostavki, da površina akumulacijskega dela ledenika zavzema določen delež celotne površine ledenika (Porter, 2000). Na današnjih odtočnih ledenikih je delež akumulacijskega dela $58 \%$ celotne površine (Ignéczi, Nagy, 2012), za ledenike z debelim drobirskim plaščem pa znaša delež 40 \% (Kulkarni, 1992). Za izračun pleistocenske ravnovesne meje na Trnovskem gozdu smo uporabili vrednost $50 \%$, ki predstavlja približno srednjo vrednost med odtočnimi ledeniki in ledeniki z drobirskim plaščem.

Metoda zgornje meje bočnih moren predpostavlja, da pri ledeniku v stabilnem stanju zgornja meja bočnih moren sovpada z minimalno višino ravnovesne meje (Lichtenecker, 1938; cv: Benn, Lehmkuhl, 2000), kar je dober približek nekdanje ravnovesne meje (Porter, 2000).

\section{REZULTATI}

\section{I. Sledovi poledenitve}

Med temeljitim terenskim pregledom Trnovskega gozda smo sledove pleistocenske poledenitve identificirali le severno od Golakov. Na Čavnu, Mrzovcu in južnih pobočjih 
Golakov nismo našli nikakršnih neposrednih ali posrednih ledeniških oblik, ki jih navajata Habič (1968) in Melik (1959). Zaradi odsotnosti geomorfoloških dokazov zaključujemo, da ta območja niso bila poledenela.

Vse ledeniške akumulacije, ki smo jih identificirali na severnih pobočjih Golakov, gradi drobnozrnata frakcija norijsko-retijskega dolomita z večjimi zaobljenimi kosi dachsteinskega apnenca. Na planoti okoli Škrbine, ki leži med Poslušanjem, Sončnim robom, Bukovim vrhom in pobočji Golakov, so manjše zaplate ledeniških akumulacij, ki jih navaja že Habič (1968). Na južnem pobočju Bukovega vrha je večja zaplata talne morene, ki sega do nadmorske višine 1280 m (slika 2). Na vzhodnem delu planote med Poslušanjem in Sončnim robom so peščeno-gruščnate akumulacije norijsko-retijskega dolomita, ki ne vsebujejo apnenčastih blokov. Ista struktura in litološka sestava klastov je v akumulacijah na Hudem polju. Pri terenskem pregledu smo ugotovili, da leži celotno Hudo polje na tektonsko zdrobljenih norijsko-retijskih dolomitih, saj območje seka čepovanski prelom; posledično je debelina dolomitne prepereline na Hudem polju in okoliških pobočjih velika. Ker akumulacij ne moremo ločiti od preperele matične podlage, jim ne moremo pripisati ledeniškega izvora, kar je v nasprotju s trditvami Habiča (1968).

Sledove poledenitve smo identificirali le v tistih kontah in dragah, kjer je led odtekal preko njihovega oboda in odlagal morensko gradivo. Tako smo na območju Črne drage identificirali talne in bočne morene (slika 3). V dnu Črne drage je obsežna talna morena, ki jo je identificiral že Habič (1968). Na severnem pobočju Črne drage je pod Poslušanjem daljši nasip bočne morene na nadmorski višini okoli $1210 \mathrm{~m}$. Na njenem severozahodnem pobočju sta dva vzporedna grebena bočnih moren, ki se začneta na nadmorskih višinah 1190 in 1170 m, zaključita pa se na nadmorski višini $1160 \mathrm{~m}$. Po jugovzhodnem pobočju Črne drage pod Ciganskim vrhom potekata dva nekoliko bolj izrazita grebena, od katerih se daljši začne na nadmorski višini $1250 \mathrm{~m}$. Zaključita se tik nad ostrim pregibom v dolino Belce na nadmorski višini $1140 \mathrm{~m}$.

Tudi v Smrekovi dragi smo našli obsežne ledeniške akumulacije; nekatere izmed njih so opisovali že Melik (1959), Buser (1965) in Habič (1968). Celoten severni rob drage do višine $1250 \mathrm{~m}$ prekriva morensko gradivo. Na vzhodnem obodu drage je daljši greben bočne morene, ki se prične na nadmorski višini okoli $1300 \mathrm{~m}$ in se zaključi nad dolino Trebuše. Ledeniške akumulacije so tudi v nekaterih kontah severno od Smrekove drage. Kljub navedbam Habiča (1968), da je na dnu Mojske drage čelni nasip, dokazov za obstoj kakršnekoli ledeniške akumulacije tam nismo našli.

V povirnem delu doline Trebuše smo jugovzhodno od kmetije Šinkovec in južno od zaselka Sedejski Grič našli dva izrazita grebena bočnih moren, ki ležita 80 in $50 \mathrm{~m}$ nad dnom doline. Najskrajnejše ledeniške akumulacije smo našli v severnem pobočju doline, le okoli $10 \mathrm{~m}$ nad sedanjim dnom in okoli $300 \mathrm{~m}$ pred sotočjem Trebuše s potokom Jelenk pri Gorenji Trebuši. 
Slika 2: Talna morena na Bukovem vrhu (foto: B. Kodelja)

Figure 2: Ground moraine on Bukov vrh (photo: B. Kodelja)

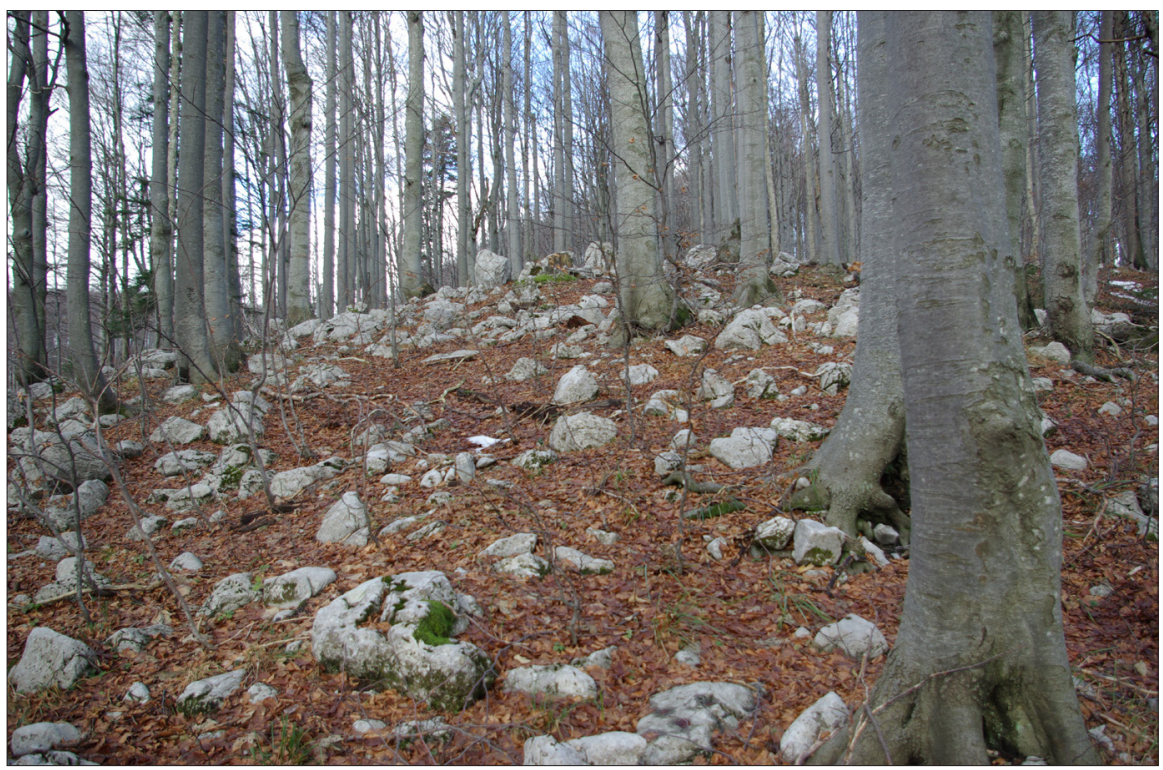

Slika 3: Geomorfološka karta ledeniških oblik na Trnovskem gozdu

Figure 3: Geomorphological map of glaciation features on Trnovski gozd

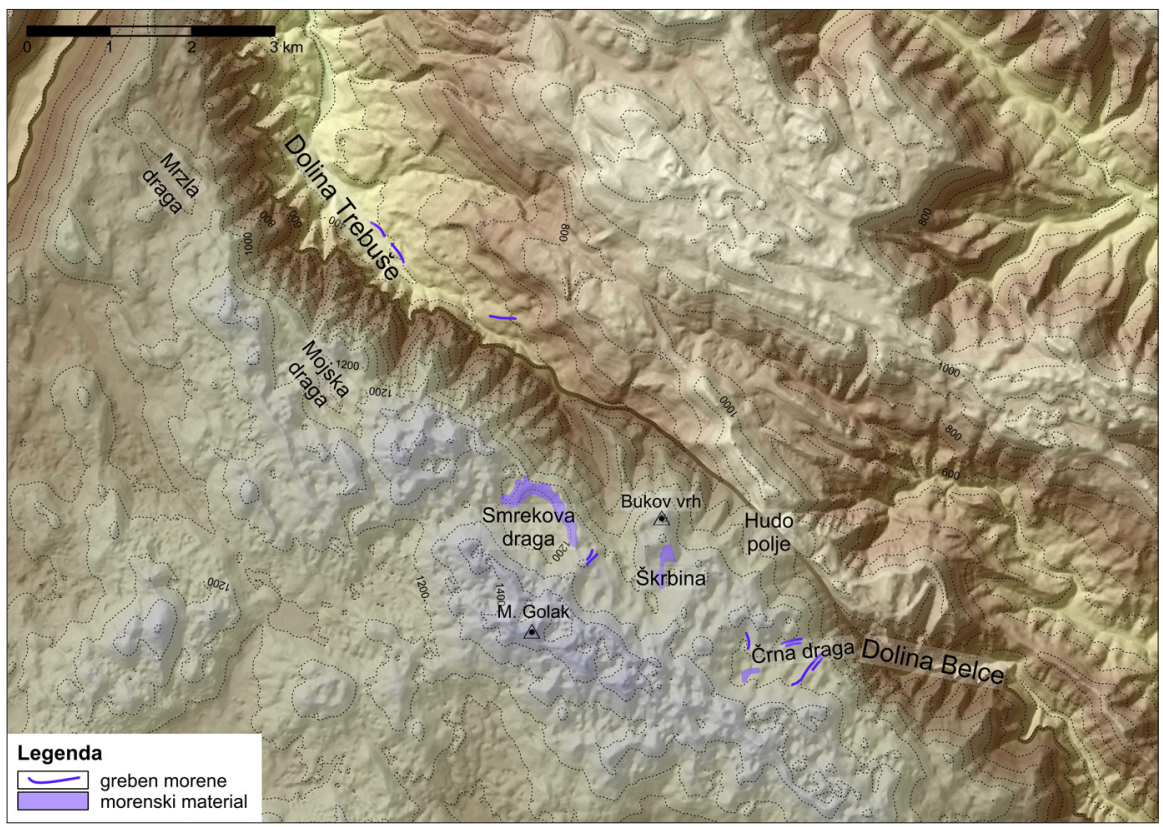




\subsection{Topografija ledenikov}

Površina pleistocenske poledenitve na Trnovskem gozdu je bila okoli $8 \mathrm{~km}^{2}$. Iz te vrednosti so izvzete vse konte, za katere predvidevamo, da so bile zapolnjene $\mathrm{z}$ ledom. Prav tako v to vrednost ni všteta površina odtočnih ledenikov v dolini Belce, na Hudem polju in v povirnem delu doline Trebuše vzhodno od Bukovega vrha, saj tam nimamo neposrednih dokazov, da bi lahko ugotovili, na kateri nadmorski višini se je ledenik zaključil.

Osrednji greben Golakov je v času poledenitve predstavljal erozijsko območje ledenikov. Konte na grebenu so bile ob višku poledenitve do roba zapolnjene z ledom, večina ledu iz kont pa je po severnih pobočjih Golakov odtekala v Črno drago, na planoto okoli Škrbine in v Smrekovo drago (slika 5). Planotasto površje pod severnimi pobočji Golakov so prekrivali trije ledeniki s skupno površino $4,8 \mathrm{~km}^{2}$.

Ledenik v Črni dragi je dosegal debelino $90 \mathrm{~m}$. V obliki $40 \mathrm{~m}$ debelega in $260 \mathrm{~m}$ širokega odtočnega ledenika je najverjetneje padal preko strmega pobočja v dolino Belce.

Največji ledenik na območju Trnovskega gozda je bil na planoti okoli Škrbine in je bil debel $140 \mathrm{~m}$ (slika 5). Povezan je bil z ledenikom v Črni dragi. Iz njega so odtekali trije odtočni ledeniki v tri različne smeri: proti Hudemu polju je odtekal $30 \mathrm{~m}$ debel in $460 \mathrm{~m}$ širok odtočni ledenik, v povirni del doline Trebuše vzhodno od Bukovega vrha pa $50 \mathrm{~m}$ debel in $330 \mathrm{~m}$ širok odtočni ledenik. Največji odtočni ledenik je odtekal proti severozahodu zahodno od Bukovega vrha v dolino Trebuše in je bil okoli $30 \mathrm{~m}$ debel ter več kot $400 \mathrm{~m}$ širok.

Ledenik z največjo debelino ledu okoli $180 \mathrm{~m}$ je bil na območju Smrekove drage. $\mathrm{Na}$ več mestih je odtekal preko severozahodnega oboda konte $\mathrm{v}$ dolino Trebuše, kjer se je združil z odtočnim ledenikom s planote okoli Škrbine. Združen odtočni ledenik je odtekal skoraj $4 \mathrm{~km}$ daleč po dolini Trebuše navzdol in se zaključil okoli $300 \mathrm{~m}$ pred sotočjem Trebuše s potokom Jelenk na nadmorski višini okoli $350 \mathrm{~m}$. Na podlagi izrazitih bočnomorenskih nasipov v dolini Trebuše lahko zanesljivo trdimo, da je imel spodnji del ledenika značilnosti ledenika z drobirskim plaščem (Benn, Evans, 1998).

Konte in drage nad ravnovesno mejo so bile $\mathrm{v}$ celoti zapolnjene $\mathrm{z}$ ledom. Na podlagi meritev temperatur v kraških kotanjah (Hribar, 1960; Hočevar, Martsolf, 1971; Petkovšek, Gams, Hočevar, 1969; Ogrin, D., Ogrin, M., 2005; Ogrin, M., 2007) lahko sklepamo, da je vertikalni temperaturni gradient $\mathrm{v}$ kontah in drugih reliefnih kotanjah linearen in ima vrednosti okoli $6{ }^{\circ} \mathrm{C}$ na $100 \mathrm{~m}$. Ker je vertikalni temperaturni gradient $\mathrm{v}$ kotanjah okoli desetkrat višji od okoliškega temperaturnega gradienta, lahko predvidevamo, da so bile tudi konte pod ravnovesno mejo zapolnjene $\mathrm{z}$ ledom, vendar ne $\mathrm{v}$ celoti, temveč do nekaj metrov pod najnižjo točko oboda, odvisno od njihove nadmorske višine. 
Slika 4: Ledeniški material na pobočju Smrekove drage (foto: B. Kodelja)

Figure 4: Glacial material on the slope of Smrekova draga (photo: B. Kodelja)

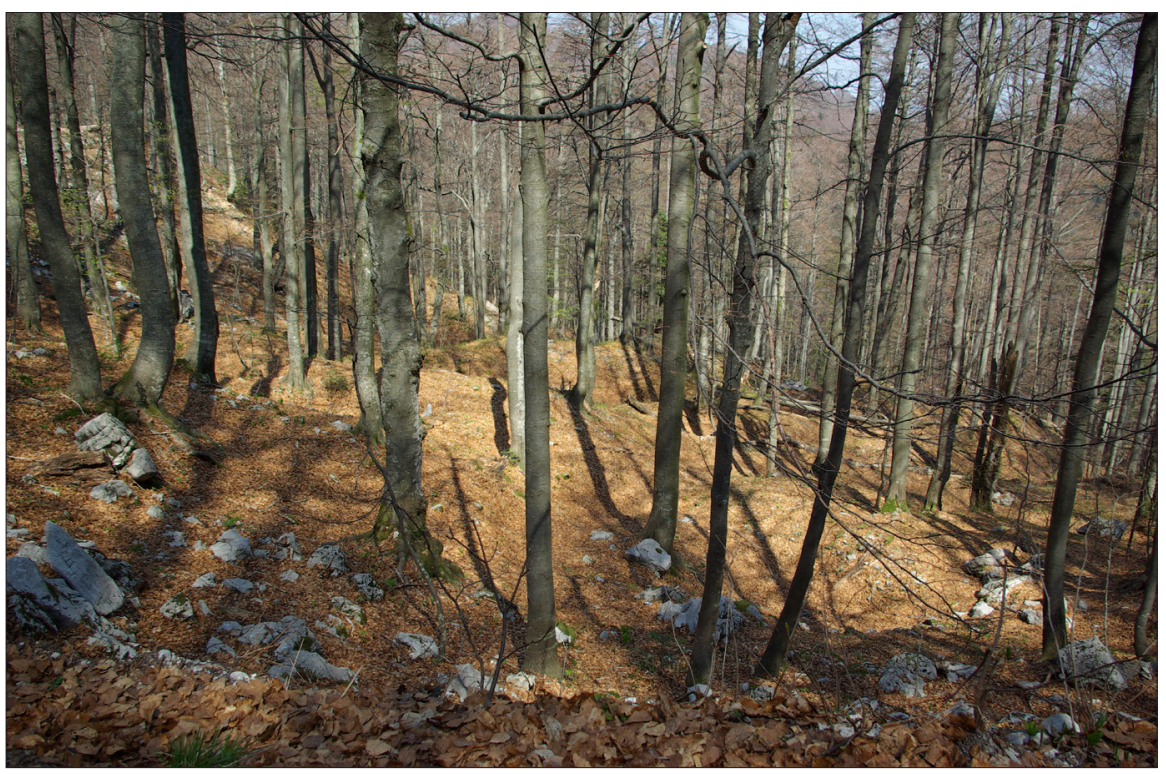

Slika 5: Rekonstrukcija pleistocenske poledenitve Trnovskega gozda

Figure 5: Reconstruction of the Pleistocene glaciation on Trnovski gozd

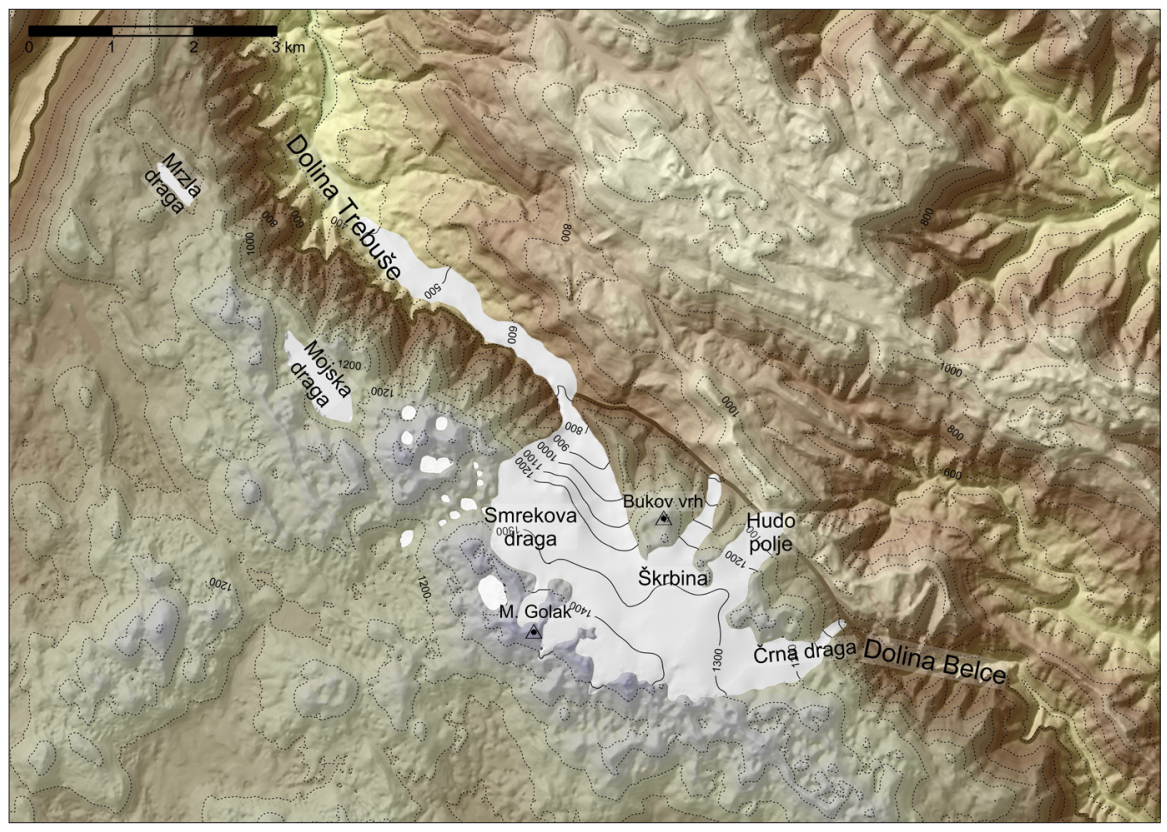




\subsection{Ravnovesna meja ledenikov}

Ravnovesno mejo ledenikov smo na Trnovskem gozdu rekonstruirali na območjih, kjer smo imeli dovolj morfometričnih podatkov za aplikacijo posamezne metode. Metodo deleža akumulacijskega dela ledenika smo uporabili le na odtočnem ledeniku, ki je padal v dolino Trebuše. Zanj vemo, na kateri nadmorski višini se je zaključil, zato smo lahko rekonstruirali celotno njegovo površino. Na osnovi 50-odstotnega deleža smo izračunali, da se je ravnovesna meja nahajala na nadmorski višini 1260 m. Po metodi zgornje meje bočnih moren smo ravnovesno mejo izračunali le za ledenik v Črni dragi, kjer so ohranjene izrazite bočne morene. Povsod drugje na Trnovskem gozdu se zaradi prestrmega reliefa morenski material v obliki bočnih moren ni odložil ali pa so ga odstranili poznejši pobočni procesi. Ravnovesna meja v Črni dragi, izračunana glede na povprečno višino najvišjih bočnih moren na nasprotnih pobočjih, znaša $1220 \mathrm{~m}$. Na osnovi obeh metod smo ugotovili, da je bila pleistocenska ravnovesna meja ledenikov na Trnovskem gozdu $\mathrm{v}$ povprečju na nadmorski višini $1240 \mathrm{~m}$.

$\mathrm{V}$ kontah in dragah, ki so bile v celoti pod ravnovesno oziroma snežno mejo, se je pod njihovim najnižjim delom oboda zaradi temperaturne inverzije oblikovala inverzna snežna meja; posledično so bile zapolnjene z ledom. Če poznamo vertikalni temperaturni gradient $\mathrm{v}$ kotanjah in $\mathrm{v}$ okolici ter višino pleistocenske ravnovesne meje, lahko za te kotanje izračunamo povprečno višino, do katere so bile zapolnjene z ledom. Na podlagi povprečnega vertikalnega temperaturnega gradienta v kraških kotanjah (Hočevar, Martsolf, 1971) smo izračunali višino zapolnitve v dveh največjih dragah, ki sta se ob višku zadnje poledenitve nahajali pod višino ravnovesne meje. Mojsko drago je led zapolnjeval do nadmorske višine $1150 \mathrm{~m}$, kar je $10 \mathrm{~m}$ pod najnižjim delom oboda, višina ledene zapolnitve v Mrzli dragi pa je bila na 975 m, kar je okoli 25 m pod najnižjim delom oboda.

\section{SKLEP}

Glavni namen raziskave je bil reinterpretacija dosedanjih ugotovitev obsega poledenitve na Trnovskem gozdu in rekonstrukcija ravnovesne meje ledenikov. Preučevano območje je obsegalo najvišje predele Trnovskega gozda in vsa območja, za katera literatura posredno ali neposredno navaja ledeniško preoblikovanje.

$\mathrm{Z}$ morfografsko analizo ledeniških erozijskih in akumulacijskih oblik so bili ugotovljeni sledovi poledenitve na območju Črne drage, planote okoli Škrbine, Smrekove drage in v dolini Trebuše. Na podlagi nadmorskih višin nekaterih ledeniških akumulacij posredno sklepamo, da so ledeniki odtekali tudi na Hudo polje ter v dolini Belce in Trebuše. Na območjih Mrzovca, Čavna in južnih pobočij Golakov kljub navedbam v predhodni literaturi (Melik, 1959; Buser, 1965; Habič, 1968) sledov poledenitve nismo našli.

Terenske morfografske in morfometrične podatke o ledeniških akumulacijah smo uporabili pri numeričnem modeliranju teoretičnega podolžnega profila ledeniškega površja, na osnovi katerega smo izdelali topografijo ledenikov na Trnovskem gozdu. Površina ledenika je bila okoli $4,8 \mathrm{~km}^{2}$, njegova največja debelina pa je na območju Smrekove drage znašala okoli $180 \mathrm{~m}$. Odtočni ledeniki so preko strme reliefne stopnje padali v obliki 
serakov ali ledeniških plazov. Najnižje je segal odtočni ledenik s planote okoli Škrbine in Smrekove drage v dolino Trebuše in se zaključil na nadmorski višini okoli $350 \mathrm{~m}$. Skupna površina pleistocenskih ledenikov na Trnovskem gozdu je po naših ugotovitvah znašala vsaj $8 \mathrm{~km}^{2}$, kar je bistveno manj, kot je predvidevala starejša literatura.

Morfokronološke analize poledenitve zaradi odsotnosti primernega materiala za datacije nismo opravili. Ker sprijetih moren oz. tilitov na preučevanem območju nismo našli, zaključujemo, da so obseg in rekonstrukcije, ki so temeljile na prostorski razporeditvi nesprijetih moren, izdelane za višek zadnje poledenitve, saj so morene starejših poledenitvenih dogodkov navadno litificirane in delno preoblikovane s površinskimi procesi. Vsekakor bo potrebno in smiselno v prihodnje opraviti sistematične datacije ledeniških akumulacij.

Morfometrične podatke o ledeniških akumulacijah ter topografijo ledenikov smo uporabili pri izračunih ravnovesne meje ledenikov. Na podlagi metod deleža akumulacijskega dela ledenika in zgornje meje bočnih moren smo izračunali, da se je pleistocenska ravnovesna meja na Trnovskem gozdu v povprečju nahajala na nadmorski višini $1240 \mathrm{~m}$. Ta meja je na severni polobli najnižja na severovzhodnih ekspozicijah (Benn, Evans, 1998), zato rekonstruirana ravnovesna meja predstavlja najnižjo ravnovesno mejo na Trnovskem gozdu. Višina pleistocenske ravnovesne meje na Trnovskem gozdu je primerljiva z višino ravnovesne meje v predgorju Julijskih Alp, kjer so bili v času viška zadnje poledenitve manjši ledeniki, po površini primerljivi z obsegom poledenitve Trnovskega gozda, neodvisni od ledenika v dolini Tilmenta. Ravnovesna meja teh ledenikov je bila med 1150 in $1200 \mathrm{~m}$ (Monegato, 2012).

Odsotnost ledeniških oblik na prisojnih pobočjih Golakov nakazuje na prostorsko izjemno asimetrično poledenitev Trnovskega gozda, kar je posledica topografije površja in posledično mikroklimatskih značilnosti. Strma reliefna stopnja nad Vipavsko dolino in dinarska usmerjenost Trnovskega gozda pomembno vplivata na razlike v količini padavin med privetrno in zavetrno stranjo. Največjo količino padavin na Trnovskem gozdu prejmejo zavetrna in osojna pobočja Golakov, in sicer $15 \%$ več v primerjavi s prisojnimi pobočji (Peternel, 2007). Zaradi manjše intenzitete Sončevega obsevanja pa so povprečne letne temperature na osojnih pobočjih nižje kot v okolici. Razlika v nadmorski višini med bližnjimi ledeniki s severno in južno ekspozicijo lahko teoretično znaša od 70 do $320 \mathrm{~m}$ (Evans, Cox, 2005). Razlike v ravnovesni meji med severnimi in južnimi ekspozicijami so največje na srednjih geografskih širinah, visokih nadmorskih višinah in strmih ter površinsko majhnih ledenikih (Evans, 2006). Na prisojni strani Golakov bi se torej morala ravnovesna meja nahajati nekje na intervalu od 1310 do $1560 \mathrm{~m}$. Predvidevamo, da je bila ravnovesna meja na južnih pobočjih Golakov nad 1400 m, nad to višino pa ni topografskega zaledja, kjer bi se led lahko akumuliral.

\section{Viri in literatura}

Benn, D. I., Lehmkuhl, F., 2000. Mass balance and equilibrium-line altitudes of glaciers

in high-mountain environments. Quaternary international, 65-66, str. 15-29.

Benn, D. I., Evans, D. J. A., 1998. Glaciers and glaciation. London, Arnold, 734 str. 
Benn, D. I., Hulton, N. R. J., 2010. An Excel ${ }^{\mathrm{TM}}$ M spreadsheet program for reconstructing the surface profile of former mountain glaciers and ice caps. Computers and geosciences, 36, 5, str. 605-610.

Buser, S., 1965. Geološke razmere v Trnovskem gozdu. Geografski vestnik, 37, str. 123-135.

Evans, I. S., 2006. Local aspect asymmetry of mountain glaciation: a global survey of consistency of favoured directions for glacier numbers and altitudes. Geomorphology, $73,1-2$, str. 166-184.

Evans, I. S., Cox, N. J., 2005. Global variations of local asymmetry in glacier altitude: separation of north-south and east-west components. Journal of glaciology, 51, 174, str. 469-482.

GURS, 2005. Digitalni model reliefa 12,5 m. Geodetska uprava Republike Slovenije. Ljubljana.

Habič, P., 1968. Kraški svet med Idrijco in Vipavo. Ljubljana, Slovenska akademija znanosti in umetnosti, 243 str.

Hočevar, A., Martsolf, J. D., 1971. Temperature distribution under radiation frost conditions in a central Pennsylvania valley. Agricultural meteorology, 8, str. 371-383.

Hribar, F., 1960. Temperatur und Vegetationsumkehrungen in Trnovski gozd. V: Popović, V. M., (ur.). 6ème congrès international de météorologie alpine, Bled, Yougoslavie, 14.-16. septembre 1960. Beograd, Hidrometeorološki institut SFRJ, str. 312-344.

Ignéczi, Á., Nagy, B., 2012. Determining steady-state accumulation-area ratios of outlet glaciers for application of outlets in climate reconstructions. Quaternary international, 293, str. 268-274.

Janež, J., Čar, J., Habič, P., Podobnik, R., 1997. Vodno bogastvo Visokega krasa. Ranljivost kraške podzemne vode Banjšic, Trnovskega gozda, Nanosa in Hrušice. Idrija, Geologija, 167 str.

Klimatografija Slovenije. Padavine 1951-1980. 1989. Ljubljana, Hidrometeorološki zavod SR Slovenije, 393 str.

Kulkarni, A. V., 1992. Mass balance of Himalayan glaciers using AAR and ELA methods. Journal of glaciology, 38, str. 101-104.

Lichtenecker, N.,1938. Die gegenwärtige und die eiszeitliche Schneegrenze in den Ostalpen. In: Verhandlungen der III. internationalen Quartär-Konferenz, Wien, 1936, str. 141-147.

Meier, M. F., Post, A. S., 1962. Recent variations in mass net budgets of glaciers in western North America. International Association of scientific hydrology, 58, str. 63-77.

Melik, A., 1959. Nova geografska dognanja na Trnovskem gozdu. Geografski zbornik, 5, str. 5-25.

Mihevc, A., 1995. The morphology of shafts on the Trnovski gozd plateau in west Slovenia. Cave and karst science, 21, 2, str. 67-69.

Mihevc, A., 1997. Speleological properties of the area. V: Kranjc, A., (ur.). Karst hydrogeological investigations in south-western Slovenia. Acta carsologica, 26, 1, str. 57-68.

Monegato, G., 2012. Local glaciers in the Julian Prealps (NE Italy) during the last glacial maximum. Alpine and Mediterranean Quaternary, 25, str. 5-14.

Ogrin, D., Ogrin, M., 2005. Predhodno poročilo o raziskovanju minimalnih temperatur v mraziščih pozimi 2004/2005. Dela, 23, str. 221-233. 
Ogrin, D., 1996. Podnebni tipi v Sloveniji. Geografski vestnik, 68, str. 39-56.

Ogrin, D., Plut, D., 2009. Aplikativna fizična geografija Slovenije. Ljubljana, Znanstvena založba Filozofske fakultete, 246 str.

Ogrin, M., 2007. The minimum temperatures in the winter 2006/07 in Slovenian frost hollows and cold basins. Dela, 28, str. 221-237.

Osnovna geološka karta SFRJ. List Gorica. 1968. 1:100.000. Beograd, Zvezni geološki zavod.

Osnovna geološka karta SFRJ. List Tolmin in Udine (Videm). 1986. 1:100.000. Beograd, Zvezni geološki zavod.

Paterson, W. S. B., 1994. The physics of glaciers. Oxford, Butterworth-Heinemann, 496 str.

Peternel, T., 2007. Prostorsko spreminjanje padavin na profilu čez Trnovski gozd. Diplomsko delo. Ljubljana, Filozofska fakulteta, Oddelek za geografijo, 90 str.

Petkovšek, Z., Gams, I., Hočevar, A., 1969. Meteorološke razmere v profilu Drage. Zbornik Biotehniške fakultete Univerze v Ljubljani, 16, str. 13-24.

Porter, S. C., 1975. Glaciation limit in New Zealand's Southern Alps. Arctic and Alpine research, 7, 1, str. 33-37.

Porter, S. C., 2000. Snowline depression in the tropics during the last glaciation. Quaternary science reviews, 20, 10, str. 1067-1091.

Repe, B., 2010. Prepoznavanje osnovnih prsti slovenske klasifikacije. Dela, 34, str. 143-166.

Torsnes, I., Rye, N., Nesje, A., 1993. Modern and Little Ice Age equilibrium-line altitudes on outlet valley glaciers from Josteldalsbreen, Western Norway: an evaluation of different approaches to their calculation. Arctic and Alpine research, 25, 2, str. 106-116.

\section{TRACES OF PLEISTOCENE GLACIATION ONTRNOVSKI GOZD}

\section{Summary}

Trnovski gozd is the northernmost tip of the Dinaric Mountains and is situated in western Slovenia. It is a high plateau on an elevation of about $900 \mathrm{~m}$, with some higher areas reaching an elevation of up to $1495 \mathrm{~m}$ at the highest peak Mali Golak. It is mainly built of Triassic and Jurassic limestones and dolomites, resulting in the complete dominance of a karst geomorphic system. The area of Trnovski gozd was also remodelled by glacial action in Pleistocene.

The main aim of this research was to reinterpret previous findings regarding the extent of glaciation in the area, and to calculate the equilibrium line altitude of the Last Glacial Maximum. The study area included the highest parts of Trnovski gozd as well as those areas suggested by previous authors to have been directly or indirectly altered by glaciation.

Traces of glaciation were identified through morphographic analyses of glacial erosion and accumulation landforms. Glacially modified surfaces were identified on the northern slopes of the highest ridge of Golaki. They were also found in the areas of Črna draga, Škrbina plateau and Smrekova draga close to the northern edge of the Trnovski gozd. The lowest glacial accumulation was identified in the valley of Trebuša on an elevation of about $350 \mathrm{~m}$. According to the positions of some glacial accumulations, we 
assume that glaciers were present also on the Hudo polje plateau and in the valley of Belca. We did not find any morphographical evidence of glacial action on the ridges of Mrzovec, Čaven or the southern slopes of Golaki, contrary to the suggestion of earlier studies (Melik, 1959; Buser, 1965; Habič, 1968).

Field morphographic and morphometric data of glacial accumulations were used for the numeric modelling of theoretical longitudinal profiles of glacial surfaces (Benn, Hulton, 2010) which we utilised for modelling the glacial surface topography of the whole study area. The glacier on Trnovski gozd plateau covered an area of about $4.8 \mathrm{~km}^{2}$, its greatest depth being $180 \mathrm{~m}$. Outlet glaciers were found to have been plunging as icefalls down the steep northern edge of the plateau into the valleys of Trebuša and Belca. The total glaciated area of the Trnovski gozd was calculated to have been $8 \mathrm{~km}^{2}$.

Morphometric data of glacial accumulations as well as modelled glacial surface topography was used for calculating the equilibrium line altitude (ELA) of the Last Glacial Maximum. It was established to $1240 \mathrm{~m}$ on basis of the accumulation-area ratio method and the method of maximum elevation of lateral moraines. The equilibrium line altitude was calculated only for slopes with northern exposure where glaciers were present. Absence of glacial landforms on slopes with southern exposition shows significant asymmetry of glaciation in the study area. This is likely to be due to significant difference of precipitation between the windward and leeward sides of the highest ridge (Peternel, 2007). We assume that the equilibrium line altitude of the Last Glacial Maximum on slopes with southern exposition was higher than $1400 \mathrm{~m}$ as there is no suitable hinterland for the formation of glaciers, otherwise at least some evidence of glaciation would have been preserved. 